\title{
Seroprevalence of hepatitis B: Do blood donors represent the general population?
}

\author{
Hayat Kumbasar Karaosmanoglu, Ozlem Altuntas Aydin, Semra Sandikci, Emine Rahsan \\ Yamanlar, Ozcan Nazlican
}

Infectious Diseases and Clinical Microbiology, Haseki Training and Research Hospital, Istanbul, Turkey

\begin{abstract}
Introduction: In this study, we aimed to compare the HBV seroprevalances of voluntary blood donors and the healthy persons who required premarital screening.

Methodology: HBsAg ELISA results were collected retrospectively from the records of 9,949 blood donors and 954 healthy persons who required premarital screening.

Results: HBsAg was detected in 182 of 9,949 (\%1.8) voluntary blood donors and 32 of 954 (\%3.4) healthy persons who required premarital screening. HBsAg seropositivity was significiantly higher in the healthy persons who required premarital screening than in blood donors $(\mathrm{p}=0.0016)$.

Conclusion: Premarital screening is mandatory in our country, and it may provide more accurate epidemiological data to determine HBV seroprevalence than in other selected groups such as blood donors.
\end{abstract}

Key words: HBV; premarital screening; seroprevalance

J Infect Dev Ctries 2012; 6(2):181-183.

(Received 13 May 2011 - Accepted 19 December 2011)

Copyright (C) 2012 Karaosmanoglu et al. This is an open-access article distributed under the Creative Commons Attribution License, which permits unrestricted use, distribution, and reproduction in any medium, provided the original work is properly cited.

\section{Introduction}

Hepatitis B infection is still one of the most important health issues in many parts of the world. It is estimated that there are approximately 450 million hepatitis B carriers in the world and 50 million new cases are added every year [1,2]. Hepatitis B surface antigen (HBsAg) seroprevalence varies according to a country's level of development and Turkey is considered a moderate endemic country along with other Middle East countries. Approximately five million hepatitis B carriers are estimated to reside in our country, with regional differences in frequency [3]. Regional and temporal differences in hepatitis B prevalence has been the subject of numerous studies around the globe. Hepatitis B screens and epidemiological studies are important for the identification of preventive strategies as well as early diagnosis of infected patients. In this study we aimed to compare HBsAg seroprevalence in individuals who had premarital screening with that of blood donors.

\section{Methodology}

The study was conducted on 10,903 subjects who were divided into two groups. The first group was comprised of healthy individuals applying for premarital screening tests $(\mathrm{n}=954)$ at the infectious diseases outpatient clinic, and the second group was made up of voluntary blood donors $(n=9,949)$ attending the blood center of the Haseki Training and Research Hospital in Istanbul, Turkey, between January and December 2009. Blood donors consisted of individuals considered fit to donate blood upon evaluation of medical history (based on a questionnaire filled out by the applicant) and physical exam. Age, gender and HBsAg status determined by ELISA method were evaluated retrospectively from the records. Results were compared between the two study groups and analyzed by Chi-square test.

\section{Results}

Hospital records for 2009 indicated a total of 954 healthy individuals who applied to our outpatient clinic for premarital screening tests, including 487 women (51\%) and 472 men (49\%), having a mean age of 29.5 years (range: 18-81). HBsAg positivity 
was determined in 32 of 954 subjects (3.4\%). Of the HBsAg positive subjects $20(62 \%)$ were men.

Within the same period HBsAg positivity was determined in 182 of 9,949 individuals $(1.8 \%)$ approved for blood donorship. Of the total 9,949 blood donors, only 398 (4\%) were female and the mean age was 27 years (range: 18-65).

Based on HBsAg ELISA results, hepatitis B was significantly more prevalent in individuals who had the premarital screening test compared with voluntary blood donors. $(\mathrm{p}=0.0016)$.

\section{Discussion}

Prevalence of hepatitis B infection varies among countries and even among regions within a country. Due to these differences the world is categorized into low, moderate, and high endemicity regions. In our country of moderate endemicity, hepatitis B prevalence varies between $2 \%$ and $10 \%$, based on regional differences [3]. Pooled data from blood centers in various parts of Turkey determined the HBsAg carrier rate as $5.2 \%$ in $1985-1999$, while this rate dropped to $2.97 \%$ in $2000-2005$, demonstrating a statistically significant decrease. Possible reasons for this decrease were suggested as increased public consciousness, effective use of preventive measures, increased vaccination rate, and fewer soldiers in the blood donor group $[3,4]$.

In our country HBsAg seroprevalence shows a decline from east to west. A blood center in Istanbul reported $2.06 \% \mathrm{HBsAg}$ positivity among blood donors screened between 2000 and 2006 [5]. In other Western cities, namely Duzce and Kirklareli, studies on blood donors revealed $1.97 \%$ and $1.7 \%$ HBsAg positivity [6,7]. Our results on blood donors screened in 2009 indicate similarly low rates of $\mathrm{HbsAg}$ positivity.

The largest data series on HBsAg seroprevalence come from blood centers. These studies are considered to be representative of the normal population in general. However, blood donor candidates are preselected based on donor questionnaires and physical exam, and blood is drawn only from those applicants who appear at low risk of having blood-borne pathogens. Thus HbsAg seroprevalence determined from blood donors may not reflect the population in general. Indeed, a small number of epidemiologic studies in healthy cohorts determined much higher hepatitis B carrier rates in our country $[8,9,10]$. However, population-based studies aimed solely at generating epidemiological seroprevalence data are considered labor-intensive and costly.

In addition to blood donation, mandatory premarital screen is another instance where hepatitis B testing is required. In 2002 mandatory premarital hepatitis screening was added to the civil statute. In addition to Turkey, similar mandatory premarital hepatitis screens are implemented in countries such as China, Taiwan, Italy, Brazil, Saudi Arabia and Iran $[11,12]$. Since the most common route of transmission for hepatitis B is sexual intercourse, it is important to screen future couples and if one of them is infected to vaccinate the other. Considering the economic burden of chronic liver diseases this procedure can be an effective strategy for preventing the spread of disease, especially in countries with high HBsAg seroprevalence. In a study conducted in Iran, economic analysis of premarital tests were compared with the economic burden of diseases resulting from hepatitis $\mathrm{B}$ and the screen was determined to be cost-effective [13]. In addition to its role in preventing disease spread and its costeffectiveness, premarital screening can provide epidemiologic data for hepatitis B. The underlying idea in the design of this study was that since premarital screens have no selection bias and include equal ratios of men and women, they may better reflect HBsAg seroprevalence of the population in general. The results of our study support this idea, as HBsAg seroprevalence was significantly higher in individuals having premarital screening compared with that of the blood donors.

In conclusion, hepatitis B carrier rates in blood donors may not reflect the population in general owing to the selective process of blood donation through health questionnaires and physical exams, and the higher frequency of male donors in our country. Premarital screening tests may provide more accurate epidemiologic data in defining hepatitis B carrier rates in the general population.

\section{References}

1. Gluud LL and Gluud C (2009) Meta-analyses on viral hepatitis. Infect Dis Clin North Am 23: 315-330.

2. Chu CJ and Lee SD (2008) Hepatitis B virus/hepatitis C virus coinfection: epidemiology, clinical features, viral interactions and treatment. J Gastroenterol Hepatol 23: 512520

3. Özdemir D and Kurt H (2007) Hepatit B virüsu enfeksiyonlarının epidemiyolojisi. In Tabak F, Balık İ, Tekeli E, editors. Viral Hepatit 2007. Ankara: Viral Hepatitle Savaşım Derneği 108-17 (in Turkish).

4. Mistık R (2007) Türkiye'de viral hepatit epidemiyolojisi yayınlarının irdelenmesi. In Tabak F, Balık İ, Tekeli E, 
editors. Viral Hepatit 2007. Ankara: Viral Hepatitle Savaşım Derneği 208-219. (in Turkish)

5. Uzun C (2008) Kan donörlerinde HBsAg, anti-HCV, antiHIV ve RPR sonuçlarının değerlendirildirilmesi. Türk Mikrobiyol Cem Derg 38: 143-146 (in Turkish).

6. Öksüz S, Mustafa Y, Özaydın Ç, Şahin İ (2008) Düzce bölgesi kan vericilerinde $\mathrm{HBsAg}$, anti-HCV ve anti-HIV seroprevalans1. Viral Hepatit Dergisi 13: 27-30 (in Turkish).

7. Şahin D, Şahin İ, Sözeri F, Önder K (2008) Kurklareli Devlet Hastanesi Kan Merkezine başvuran donörlerde HBV, HCV ve HIV esroprevalansı: Retrospektif bir çalışma. Viral Hepatit Dergisi 13: 31-35 (in Turkish).

8. Dursun M, Ozekinci T, Ertem M, Saka G, Yilmaz S, Canoruc F (2004) Prevalance of hepatitis $C$ in adults in the south-eastern region of Anatolia: a community-based study. Hepatol Res 29: 75-80.

9. Yıldırım B, Barut S, Bulut Y, Bulut Y, Yenişehirli G, Ozdemir M (2009) Seroprevalance of hepatitis B and C viruses in the province of Tokat in the Black Sea region of Turkey: A population-based study. Turk J Gastoenterol 20: 27-30.

10. Erden S, Büyüköztürk S, Calangu S, Y1lmaz G, Palandüz S, Badur S (2003) A study of serological markers of hepatitis B and $\mathrm{C}$ viruses in İstanbul, Turkey. Med Princ Pract 12: 184188
11. Alswaidi FM, O'Brien SJ (2009) Premarital screening programmes for haemoglobinopathies, HIV and hepatitis viruses: review and factors affecting their success. J Med Screen 16: 22-28.

12. Adibi P, Hedayati S, Mohseni M (2007) Attitudes towards premarital screening for hepatitis B virus infection in Iran 14: 43-45.

13. Adibi P, Rezailashkajani M, Roshandel D, Behrouz N, Ansari S, An economic analysis of premarrige prevention of hepatitis B transmission in Iran (2004) An economic analysis of premarrige prevention of hepatitis B transmission in Iran. BMC Infect Dis 4: 31-40.

\section{Corresponding author}

Hayat Kumbasar Karaosmanoglu

Haseki Training and Research Hospital

Infectıous Diseases and Clinical Microbiology

Aksaray, Fatih

Istanbul, Turkey

GSM: +90 5064539240

Email: drhayat1@hotmail.com

Conflict of interests: No conflict of interests is declared 